\title{
Influence of the phosphate salts nature on the synthesis of apatite in a wet atmosphere
}

\author{
Rachida Elosrouti $^{1,}$,, Brahim Sallek ${ }^{1}$, Hassan Chaair $^{2}$, Khalid Digua ${ }^{2}$, Hassan Oudadesse ${ }^{3}$ \\ ${ }^{1}$ Laboratory of Agricultural Resources and Process Engineering, Faculty of Sciences Kenitra, Kenitra, Morocco \\ ${ }^{2}$ Laboratory of processes Engineering, Faculty of Science and Techniques Mohammedia, Mohammedia, Morocco \\ ${ }^{3}$ Laboratory of Materials Science, Faculty of Rennes, Rennes, France \\ Email address: \\ rachida216@yahoo.fr (R. Elosrouti)
}

\section{To cite this article:}

Rachida Elosrouti, Brahim Sallek, Hassan Chaair, Khalid Digua, Hassan Oudadesse. Influence of the Phosphate Salts Nature on the Synthesis of Apatite in a Wet Atmosphere. Science Research. Vol. 3, No. 1, 2015, pp. 1-6. doi: 10.11648/j.sr.20150301.11

\begin{abstract}
Hydroxyapatite $\left(\mathrm{Ca}_{10}\left(\mathrm{PO}_{4}\right)_{6}(\mathrm{OH})_{2}\right.$, HAP) is widely used as a bone graft substitute, potential carriers of drugs and in the purification of proteins, et could be synthesized artificially by various methods but the hydrothermal method at low temperature, which gives a good crystallinity, is often used. Moreover, several studies have shown that, in the synthesis of calcium phosphate, the nature of the final product may differ depending on the experimental conditions including the value of the initial $\mathrm{Ca} / \mathrm{P}$ ratio, the nature of the calcium salts used and influence of the residence time of the initial products used in experimental conditions. Thus, in this work, while maintaining the initial Ca / P ratio to a fixed value $(1,00 \pm 0,01)$, we followed the behavior of two initial mixtures of a calcium salt and one of two other phosphate salts (di-ammonium hydrogen phosphate and di-ammonium hydrogen phosphate) as a function of residence time in an autoclave at a temperature of $80{ }^{\circ} \mathrm{C}$ in a saturated water vapor environment. The characteristics of the final product were carried out by four methods: X-ray diffraction, infrared absorption spectroscopy in the range $400 \mathrm{~cm}^{-1}{ }_{4} 4000 \mathrm{~cm}^{-1}$, chemical analysis, and scanning electron microscopy. The XRD analysis has shown that the products obtained have all an apatite structure. They show the presence, alongside that of apatite, the identifiable stripes of the calcite for the residence times in the experience that are less than 48 hours. Similarly, the infrared absorption spectroscopy for short residence times ranging from 2 hours to 8 am always have shown the presence of the bands specific to the CO32- ions which are fit for calcite and which decrease by increasing the residence time. Beyond this time, in the two experimental conditions, we note the total disappearance of these bands after 48 hours. Beyond 48 hours, by chemical analysis the atomic ratio $\mathrm{Ca} / \mathrm{P}$ remains practically constant and equal to $1.60 \pm 0.01$ for salts $\left(\mathrm{NH}_{4}\right) \mathrm{H}_{2} \mathrm{PO} 4$ and $1.58 \pm 0.01$ synthesized from the salts $\left(\mathrm{NH}_{4}\right) \mathrm{H}_{2} \mathrm{PO}_{4}$ within experimental error. Also, the SEM photographs have shown the presence of a phase formed of a needle agglomerate.
\end{abstract}

Keywords: Synthesis, Hydrothermal, Wet Atmosphere, Calcite, Phosphate Salt, Apatite

\section{Introduction}

The hydroxyapatite $\left(\mathrm{Ca}_{10}\left(\mathrm{PO}_{4}\right)_{6}(\mathrm{OH})_{2}, \mathrm{HAP}\right)$ is the main constituent of human bone. By its excellent biocompatibility and its bone conductivity, this artificially synthesized compound, is widely used as a bone graft substitute, a potential holder of drugs, and in the purification of proteins [1-4]. For its synthesis, many methods have been developed. But, the hydrothermal method at low temperature, that gives good crystallinity, is often used [5,6].

However, the physicochemical characteristics of the calcium phosphate primarily depend to their $\mathrm{Ca} / \mathrm{P}$ molar ratio, which is in turn directly related to the selected conditions during the synthesis process. Thus, several studies have investigated the influence of some synthesis parameters on the stoichiometry of calcium phosphate, including the atomic ratio [7-10]. Other studies have addressed the influence of the nature of the calcium salt [11] or the influence of residence time on the synthesis of calcium phosphate [12]. The results of these studies have shown that the nature of the final product may differ depending on the experimental conditions. Thus, to promote the formation of non-stoichiometric phosphate apatite calcium, it seemed interesting to study the influence of the nature of the phosphate salts on the synthesis of calcium phosphates by hydrothermal while maintaining the initial atomic ratio of calcium to phosphorus $\mathrm{Ca} / \mathrm{P}$ constant. Thus, to promote the formation of a non-stoichiometric apatitic 
calcium phosphate, it seemed interesting to study the influence of the nature of the phosphate salts on the synthesis of calcium phosphates by hydrothermal while maintaining the initial atomic ratio of calcium to phosphorus $\mathrm{Ca} / \mathrm{P}$ constant. We followed the behavior of two initial mixtures of calcium salt and one of two other phosphate salts as a function of time in an autoclave at a temperature of $80^{\circ} \mathrm{C}\left(\mathrm{T}<100^{\circ} \mathrm{C}\right)$ in a medium and saturated with water vapor $(100 \%$ moisture $)$ [12]. The calcium salt that we used in this study is the calcium carbonate $\mathrm{CaCO}_{3}$ (Prolabo), and our choice of the phosphate salt is attached to two salts, the di-ammonium hydrogen phosphate (NH4) ${ }_{2} \mathrm{HPO}_{4}$ ammonium di-hydrogen $\left(\mathrm{NH}_{4}\right)$ $\mathrm{H}_{2} \mathrm{PO}_{4}$ (Prolabo). Initial mixtures having an atomic $\mathrm{Ca} / \mathrm{P}$ ratios equal to the initial $0.01 \pm 1.00$ were homogenised by grinding, then placed in a wet atmosphere and were followed in function of time ranging from 2 hours to 21 days.

\section{Experimental Methods}

Both powder mixtures of different salts of phosphates, having a initial atomic ratio $\mathrm{Ca} / \mathrm{P}$ equal to $1.00 \pm 0.01$ were homogenized by milling and then placed in an autoclave under a wet atmosphere.

The device used to study the behavior in a wet atmosphere of mixtures of salts of calcium and phosphate (Figure-1) consists of a reactor placed in a chamber at $80^{\circ} \mathrm{C}$ and in $100 \%$ humidity. The reactor contains water to saturate the atmosphere. $27.36 \pm 0.01 \mathrm{mg}$ of the powder was spread in watch glasses and placed in the reactor for times ranging from several hours to several days. After the fixed residence time, the samples were removed from the chamber and dried during 1 hour at the selected temperature for the study. This precaution was taken to prevent any further development of the product due to the presence of adsorbed water on the surface. Then the samples were twice washed on sintered glass with distilled water and three times with a water-ethanol solution ( $50 / 50$ by volume) then dried in an oven for 4 hours. The products recovered under these conditions were calcined at $900{ }^{\circ} \mathrm{C}$ in air for two hours.

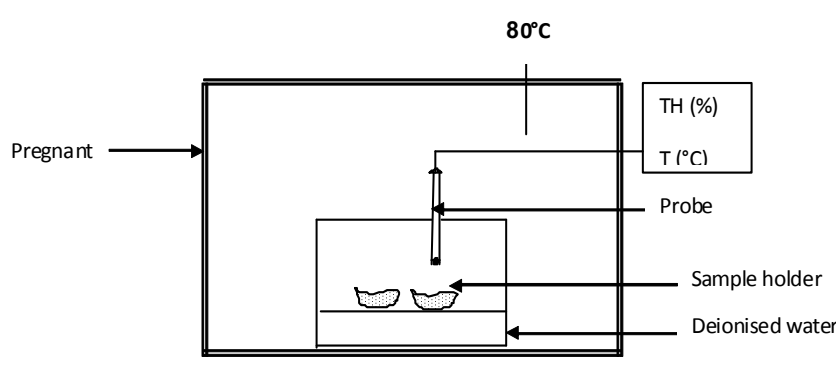

Figure 1. Experimental device.

To determine the evolution of the chemical characteristics of the products nitiaux with time, samples recovered after washing were characterized by X-ray diffraction using a diffractometer "XPERT-PRO" ( $\lambda=1.54439 \AA$ Cobalt $)$, and by infrared absorption spectroscopy which was carried out in the range $400 \mathrm{~cm}^{-1} 4000 \mathrm{~cm}^{-1}$ with a Bruker spectrometer. In IR analysis, approximately $1 \mathrm{mg}$ of the powders was thoroughly milled with $200 \mathrm{mg}$ of potassium bromide powder $\mathrm{KBr}$ in an agatat mortar. So, transparent pellets were obtained at a pressure of 15 mbar.

The examinations of the recovered powders after their washing by scanning electron microscopy (SEM) were performed on a microscope allowing a high-resolution observation; it is equipped with a complete system of X-ray microanalysis (EDX-EDAX detector), and it gives the chemical composition of the sample with a detection limit up to Bore.

The calcium was assayed in return. The complexing agent is EDTA in the presence of ammonia. The excess of EDTA used is then metered with a solution of $\mathrm{ZnCl}_{2}$.

In the studied solids, the phosphate occurs in the form of $\mathrm{HPO}_{4}{ }^{2-}$ and $\mathrm{PO}_{4}{ }^{3-}$ group. It was assayed colorimetrically at $460 \mathrm{~nm}$. The principle of this method is to measure the optical density of the yellow color of the complex vanadomolybdic phosphorus in acid medium.

The hydrogenphosphate $\mathrm{HPO}_{4}{ }^{2-}$ ions were measured after treatment of the samples at $600{ }^{\circ} \mathrm{C}$ for 20 minutes. During this heating the $\mathrm{HPO}_{4}{ }^{2-}$ ions condense to give pyrophosphate ion $\mathrm{P}_{2} \mathrm{O}_{7}^{4-}$ according to the following reaction:

$$
2 \mathrm{HPO}_{4}{ }^{2-} \rightarrow \mathrm{P}_{2} \mathrm{O}_{7}{ }^{4-}+\mathrm{H}_{2} \mathrm{O}
$$

The orthophosphate ions of the product heated were measured after hydrolysis in acid medium at $100^{\circ} \mathrm{C}$ for 1 hour. The amount of phosphorus in the form of $\mathrm{HPO}_{4}{ }^{2-}$ ions was determined by the difference between the amounts of phosphorus measured before and after hydrolysis [13].

\section{Results}

\subsection{Analysis of the Products by Infrared Spectroscopy}

The infrared absorption spectra of mixtures of various salts of phosphate treated in a wet atmosphere as a function of residence time at $80{ }^{\circ} \mathrm{C}$ are shown in Figure-2 and Figure-3. These spectra show the easily identifiable bands from their wave numbers.

For short residence times in the experience conditions ranging from 2 hours to 8 hours (curve a and b, Fig 2et3), 2cific to the calcite, located at $712 \mathrm{~cm}^{-1}, 1420 \mathrm{~cm}^{-1}$ and 1480 $\mathrm{cm}^{-1}$ [14]. Moreover, beside those of calcite, bands located at $474 \mathrm{~cm}^{-1}, 571 \mathrm{~cm}^{-1}, 602 \mathrm{~cm}^{-1}, 960 \mathrm{~cm}^{-1}, 1046 \mathrm{~cm}^{-1}$ and 1088 $\mathrm{cm}^{-1}$ and $875 \mathrm{~cm}^{-1}$ appear. Respectively these bands are characteristic of the groups $\mathrm{HPO}_{4}{ }^{2-}$ and $\mathrm{PO}_{4}{ }^{3-}$, in a non-stoichiometric apatite [15].

The total disappearance of the bands of calcite is observed for a residence time of 48 hours (curves c, fig. 2 and 3). Beyond this time, the infrared absorption spectra are similar to those of a phosphate of apatitic calcium which is deficient in calcium ions.

Indeed, in both experimental conditions, the spectra reveal further the decrease according to the time of the residence of the intensity of bands $\mathrm{HPO}_{4}{ }^{2-}$ ions and the progressive increase of the characteristics bands of $\mathrm{OH}^{-}$ions located at $3560 \mathrm{~cm}^{-1}$ and $630 \mathrm{~cm}^{-1}$. These last are most notable for the synthesized 
powders from salts $\left(\mathrm{NH}_{4}\right)_{2} \mathrm{HPO}_{4}$ and $\left(\mathrm{NH}_{4}\right) \mathrm{H}_{2} \mathrm{PO}_{4}$.

These results therefore show an evolution, according to theresidence time in the experience conditions, and of the composition, of the initial powder mixtures under wet atmosphere, to a apatite more steochiometrique.

Furthermore, the spectra of absorption of the samples of various phosphate salts treated in a wet atmosphere for 21 days, then calcined at $900^{\circ} \mathrm{C}$ (curves E, fig 2 and 3) spectra showed the presence of characteristic bands, respective of the groups $\mathrm{PO}_{4}{ }^{3-} \mathrm{OH}^{-}$and phosphate in hydroxyapatite, and those located $985 \mathrm{~cm}-1$, specific of $\mathrm{PO}_{4}{ }^{3-}$ ions of the $\beta$-tricalcium phosphate [15].

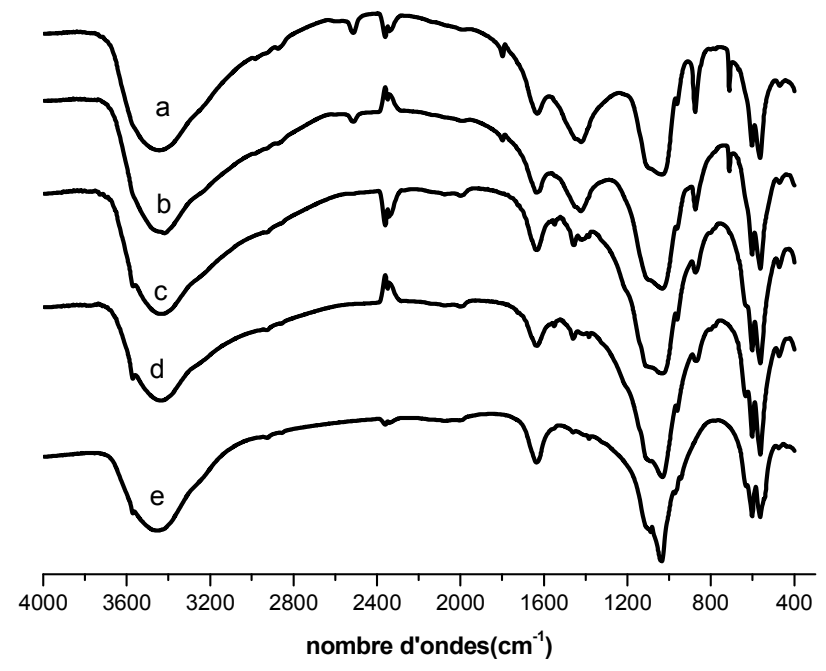

Figure 2. Infrared absorption spectra of the samples synthesized from salts $\left(\mathrm{NH}_{4}\right) \mathrm{H}_{2} \mathrm{PO}_{4}$ treated in a wet atmosphere depending on residence time (a) $2 \mathrm{~h}$, (b) 8 am, (c) 48 hours, (d) 21 d and (e) 21 d at $900^{\circ} \mathrm{C}$.

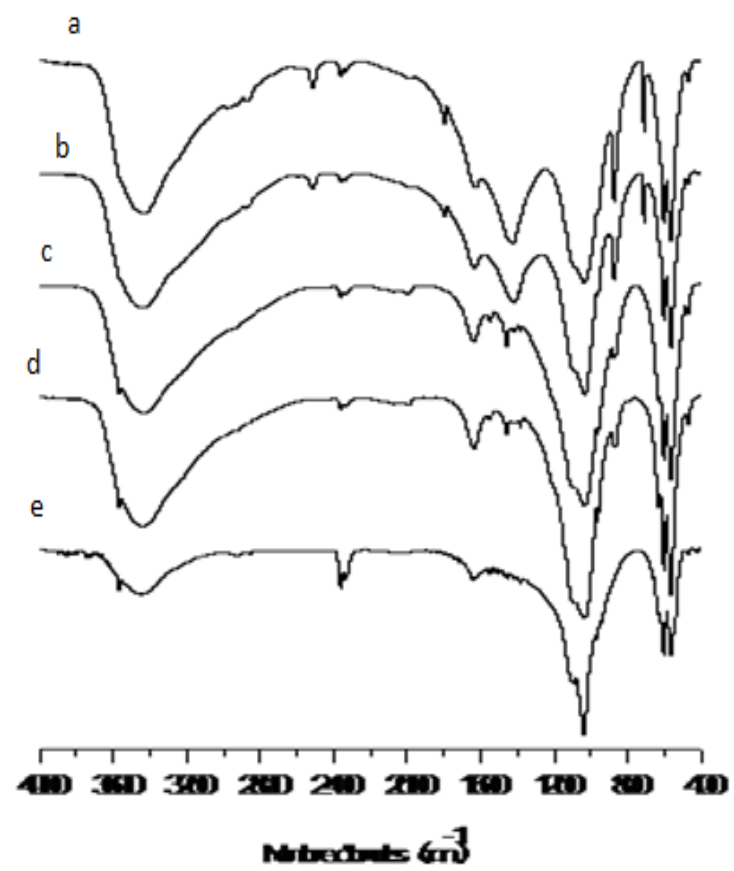

Figure 3. Infrared absorption spectra of the samples synthesized from salts $\left(\mathrm{NH}_{4}\right)_{2} \mathrm{HPO}_{4}$ treated in a wet atmosphere depending on residence time (a) $2 \mathrm{~h}$, (b) 8 am, (c) 48 hours, (d) 21 d and (e) 21 d at $900{ }^{\circ} \mathrm{C}$.

\subsection{Analysis of the Experience Products by X-ray Diffraction}

Diagrams of X-ray analysis of the samples recovered from different salts of phosphate after treatment in the conditions described above, initial atomic ratio of calcium to phosphorus $\mathrm{Ca} / \mathrm{P}$ equal to $1.00 \pm 0,01$ sont given in figure- 4 and figure-5.The X-ray diffraction analysis led to the same results as those previously disclosed by infrared spectroscopy. From 2 hours of the residence time, we have found a mixture of calcite and apatite poorly crystallized [16-17]. The calcite was identified mainly by the presence of the diffraction line at $\mathrm{d}_{104}$ $=3,035 \AA$.

When the residence time increases, the apatite phase becomes dominant and, in the final only this phase is observed. Also, it should be noted that when the time is long, the state of crystallization of the apatite was improved and these lines (002) (211) (112) and (300) are refined [17].

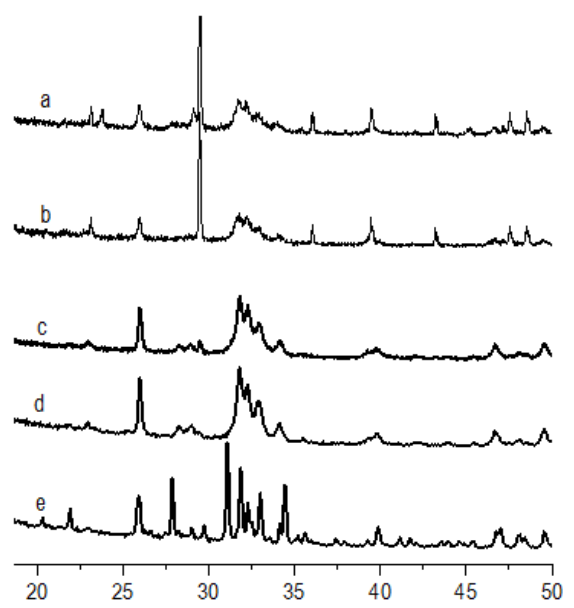

Figure 4. Diagrams of the Diffraction of X-ray of the samples synthesized from salts_( $\left.\mathrm{NH}_{4}\right) \mathrm{H}_{2} \mathrm{PO}_{4}$ treated in a wet atmosphere depending on residence time in the conditions of the experience (a) $2 \mathrm{~h}$, (b) $8 \mathrm{am}$, (c) 48 hours, (d) and $21 d$ (e) $21 d$ to $900^{\circ} \mathrm{C}$.

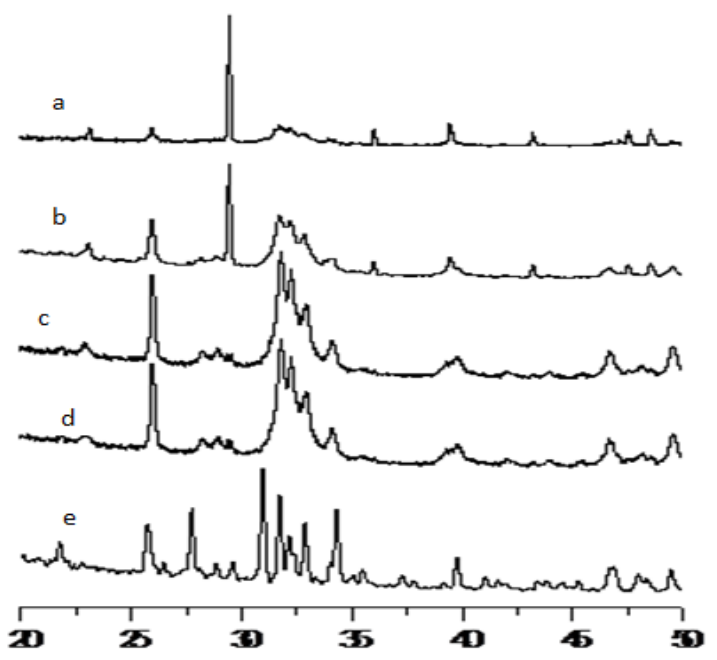

Figure 5. Diagrams of the Diffraction of X-ray of the samples synthesized from salts_( $\left.\mathrm{NH}_{4}\right)_{2} \mathrm{HPO}_{4}$ treated in a wet atmosphere depending on residence time in the conditions of the experience (a) $2 \mathrm{~h}$, (b) $8 \mathrm{am}$, (c) 48 hours, (d) and $21 \mathrm{~d}$ (e) $21 \mathrm{~d}$ to $900^{\circ} \mathrm{C}$. 
Furthermore the X-ray diagram of the products which have remained $21 \mathrm{~d}$ in the residence, then calcined at $900^{\circ} \mathrm{C}$ (curves e, Fig. 4 and 5) shows the corresponding lines to two phases we have identified : one of the phosphocalcique [16] hydroxyapatite $((214)(0210))$ and the other of the $\beta$-tricalcium phosphate (220) [18].

\subsection{Scanning Electron Microscopy}

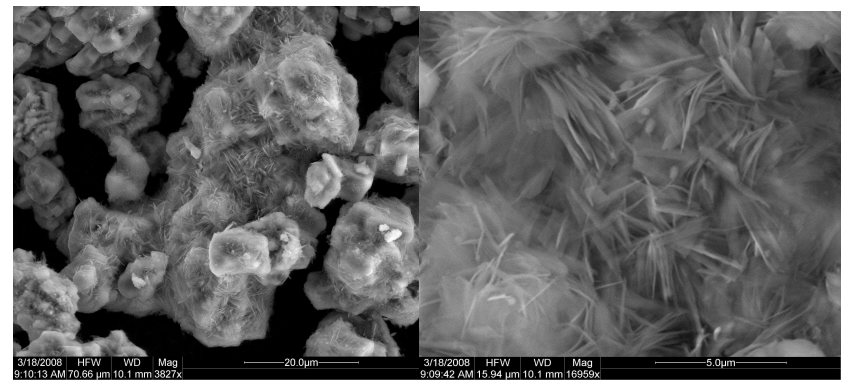

Figure 6. Obtained images in scanning electron microscopy of samples synthesized from salts $\left(\mathrm{NH}_{4}\right) \mathrm{H}_{2} \mathrm{PO}_{4}$, initial $\mathrm{Ca} / \mathrm{P}=1.00 \pm 0.01$ after treatment for 21 days at $80^{\circ} \mathrm{C}$.
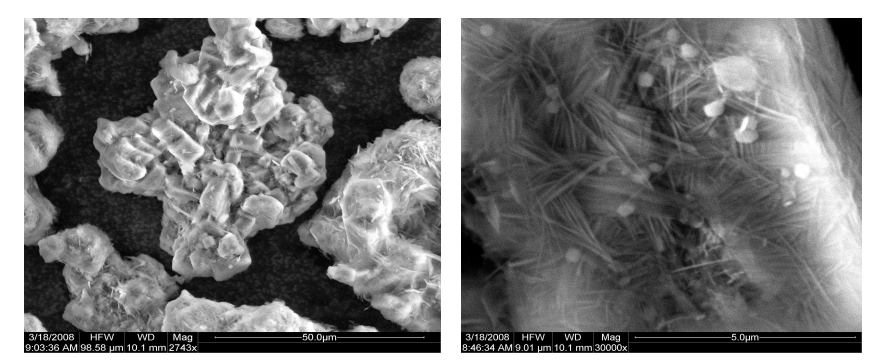

Figure 7. Obtained images in scanning electron microscopy of samples synthesized from salts $\left(\mathrm{NH}_{4}\right)_{2} \mathrm{HPO}_{4}$, initial $\mathrm{Ca} / \mathrm{P}=1.00 \pm 0.01$ after treatment for 21 days at $80^{\circ} \mathrm{C}$.

The images obtained in scanning electron microscopy revealed the presence of a phase formed of a needle agglomerate.

\subsection{Chemical Analysis of the Experience Products}

To determine the chemical composition of the products obtained, the calcium ions and orthophosphate concentrations ere determined on samples recovered from various phosphate salts after treatment in a wet atmosphere and after washing (Tables-1 and 2).

Table 1. Variations atomic ratios of the synthesized samples from the salts $\left(\mathrm{NH}_{4}\right) \mathrm{H}_{2} \mathrm{PO}_{4}$ after reaction.

\begin{tabular}{|c|c|c|c|c|c|c|c|c|}
\hline Time (in h or d) & $2 \mathbf{h}$ & $4 h$ & $8 h$ & $24 \mathbf{h}$ & $48 h$ & 3d & $7 d$ & 21d \\
\hline $\mathrm{Ca} / \mathrm{P}$ & 2.42 & 1.72 & 1.71 & 1.58 & 1.58 & 1.59 & 1.60 & 1.60 \\
\hline$\% \mathrm{HPO}_{4}{ }^{2-} / \mathrm{P}_{\mathrm{t}}$ & 6.05 & 10.49 & 13.20 & 9.32 & 8.80 & 6.70 & 6,37 & 5.63 \\
\hline I R & Apatite $+\mathrm{CaCO}_{3}$ & Apatite $+\mathrm{CaCO}_{3}$ & Apatite $+\mathrm{CaCO}_{3}$ & Apatite $+\mathrm{CaCO}_{3}$ & Apatite & Apatite & Apatite & Apatite \\
\hline DRX & Apatite $+\mathrm{CaCO}_{3}$ & Apatite $+\mathrm{CaCO}_{3}$ & Apatite $+\mathrm{CaCO}_{3}$ & Apatite $+\mathrm{CaCO}_{3}$ & Apatite & Apatite & Apatite & Apatite \\
\hline
\end{tabular}

Table 2. Variations atomic ratios of the synthesized samples from the salts $\left(\mathrm{NH}_{4}\right)_{2} \mathrm{HPO}_{4}$ after reaction.

\begin{tabular}{|c|c|c|c|c|c|c|c|c|}
\hline Time (in h or d) & $2 \mathbf{h}$ & $4 h$ & $8 h$ & $24 \mathbf{h}$ & $48 h$ & 3d & $7 d$ & 21d \\
\hline $\mathrm{Ca} / \mathrm{P}$ & 1.9 & 1.82 & 1.77 & 1.60 & 1.57 & 1.58 & 1.58 & 1.57 \\
\hline$\% \mathrm{HPO}_{4}{ }^{2-} / \mathrm{P}_{\mathrm{t}}$ & 8.97 & 8.06 & 10.46 & 9.55 & 8.03 & 6.88 & 5.66 & 5.63 \\
\hline I R & Apatite $+\mathrm{CaCO}_{3}$ & Apatite $+\mathrm{CaCO}_{3}$ & Apatite $+\mathrm{CaCO}_{3}$ & Apatite $+\mathrm{CaCO}_{3}$ & Apatite & Apatite & Apatite & Apatite \\
\hline DRX & Apatite $+\mathrm{CaCO}_{3}$ & Apatite $+\mathrm{CaCO}_{3}$ & Apatite $+\mathrm{CaCO}_{3}$ & Apatite $+\mathrm{CaCO}_{3}$ & Apatite & Apatite & Apatite & Apatite \\
\hline
\end{tabular}

we note that the $\mathrm{Ca} / \mathrm{P}$ ratio of initial mixtures progresses according to time from the value $1.00 \pm 0.01$ to the value 1.71 \pm 0.01 for the synthesized powder from $\left(\mathrm{NH}_{4}\right)_{2} \mathrm{HPO}_{4}$ to the value $1.77 \pm 0.01$ for synthesized powder from $\left(\mathrm{NH}_{4}\right) \mathrm{H}_{2} \mathrm{PO}_{4}$ after $8 \mathrm{~h}$ of residence in the condition of the experience. As it was revealed in studies by IR and XRD, this increase is mainly due to the presence of two phases: the calcite and the non steochiometric apatite. Moreover, beyond 48 hours and jusu'à 21 days, the $\mathrm{Ca} / \mathrm{P}$ remains practically constant and equal to $1.60 \pm 0.01$ for powders synthesized from salts $\left(\mathrm{NH}_{4}\right) \mathrm{H}_{2} \mathrm{PO}_{4}$ and to $1.58 \pm 0.01$ synthesized from the salts $\left(\mathrm{NH}_{4}\right)_{2} \mathrm{HPO}_{4}$ to experimental errors meadows.

Moreover, the observations made by the different techniques of analysis have led us to distinguish the formation of apatite. The X-ray diffraction and the infrared absorption spectroscopy have indicated that these phosphates have an apatitic structure. Also, this latter technique has revealed the presence of $\mathrm{PO}_{4}{ }^{3-}$ ions $\mathrm{OH}^{-}$and $\mathrm{HPO}_{4}{ }^{2-}$ which are ions belonging to the apatite phase.

Similarly, the chemical analysis samples have shown that beyond 48 hours, the apatitic calcium phosphates formed are exclusively of $\mathrm{Ca}^{2+}, \mathrm{PO}_{4}{ }^{3-}, \mathrm{HPO}_{4}{ }^{2-}$ and $\mathrm{OH}^{-}$.Tables 3 and 4 include the chemical formulas of the apatite obtained from these analyzes.

Table 3. chemical formulas apatite synthesized in a wet atmosphere at different stays in time from salt $\left(\mathrm{NH}_{4}\right) \mathrm{H}_{2} \mathrm{PO}_{4}$.

\begin{tabular}{lc}
\hline Time(in h or d) & Chemical formula \\
\hline $48 \mathrm{~h}$ & $\mathrm{Ca}_{9,47}\left(\mathrm{PO}_{4}\right)_{5,47}\left(\mathrm{HPO}_{4}\right)_{0,53}(\mathrm{OH})_{1,47}$ \\
$3 \mathrm{j} \mathrm{d}$ & $\mathrm{Ca}_{9,59}\left(\mathrm{PO}_{4}\right)_{5,59}\left(\mathrm{HPO}_{4}\right)_{0,41}(\mathrm{OH})_{1,59}$ \\
$7 \mathrm{j} \mathrm{d}$ & $\mathrm{Ca}_{9,61}\left(\mathrm{PO}_{4}\right)_{5,61}\left(\mathrm{HPO}_{4}\right)_{0,39}(\mathrm{OH})_{1,61}$ \\
$21 \mathrm{j} \mathrm{d}$ & $\mathrm{Ca}_{9,66}\left(\mathrm{PO}_{4}\right)_{5,66}\left(\mathrm{HPO}_{4}\right)_{0,34}(\mathrm{OH})_{1,66}$ \\
\hline
\end{tabular}


Table 4. chemical formulas apatite synthesized in a wet atmosphere at different stays in time from salt $\left(\mathrm{NH}_{4}\right)_{2} \mathrm{HPO}_{4}$.

\begin{tabular}{lc}
\hline Time(in h or d) & Chemical formula \\
\hline $48 \mathrm{~h}$ & $\mathrm{Ca}_{9,52}\left(\mathrm{PO}_{4}\right)_{5,56}\left(\mathrm{HPO}_{4}\right)_{0,45}(\mathrm{OH})_{1,47}$ \\
$3 \mathrm{j} \mathrm{d}$ & $\mathrm{Ca}_{9,59}\left(\mathrm{PO}_{4}\right)_{5,57}\left(\mathrm{HPO}_{4}\right)_{0,43}(\mathrm{OH})_{1,61}$ \\
$7 \mathrm{j} \mathrm{d}$ & $\mathrm{Ca}_{9,65}\left(\mathrm{PO}_{4}\right)_{5,65}\left(\mathrm{HPO}_{4}\right)_{0,35}(\mathrm{OH})_{1,63}$ \\
$21 \mathrm{j} \mathrm{d}$ & $\mathrm{Ca}_{9,65}\left(\mathrm{PO}_{4}\right)_{5,67}\left(\mathrm{HPO}_{4}\right)_{0,33}(\mathrm{OH})_{1,66}$ \\
\hline
\end{tabular}

\section{Interpretation and Discussion}

The study of the products of experence by X-ray diffraction and by the infrared absorption spectroscopy, have shown that, for the time of residence in the conditions of the experience which are greater than 48 hours, the products obtained from the two salts of phosphates, are the same: a formation of a calcium phosphate which is poorly crystallized and having apatite structure. In fact, the infrared absorption spectra of the recovered samples show the presence of the characteristic bands of the groups $\mathrm{PO}_{4}{ }^{3-}$ and $\mathrm{HPO}_{4}{ }^{2-}$ in a non-stoichiometric apatite $[15,19]$. So, these results reflect a shift of the initial mixtures under an atmosphere saturated with water vapor to an appetite which is deficient in calcium ions. In addition, at any time during the experiences, no any other phases of apatite was detected, also, the crystallization condition improves when the duration of treatment increases. Similarly, the presence of calcite in the samples treated for residence time of less than 48 hours has clearly shown that the reaction between $\mathrm{CaCO}_{3}$ and $\left(\mathrm{NH}_{4}\right) \mathrm{H}_{2} \mathrm{PO}_{4}$, or between $\mathrm{CaCO}_{3}$ and $\left(\mathrm{NH}_{4}\right)_{2}$ $\mathrm{HPO}_{4}$, in a wet atmosphere depends essentially of the duration of residence time of the intial product in the conditions of the experience.

For the characterization of the two products treated for $21 \mathrm{~d}$, then calcined at $900{ }^{\circ} \mathrm{C}$, the XRD and IR have shown an evolution of the initial salt in a wet atmosphere to a biphasic calcium phosphate apatite composed of hydroxyapatite and $\beta$-tricalcium phosphate.

By chemical analysis, the ion content of $\mathrm{Ca}^{2+}, \mathrm{PO}_{4}{ }^{3-}$ and $\mathrm{HPO}_{4}{ }^{2}$ were determined, and the atomic ratio $\mathrm{Ca} / \mathrm{P}$ was calculated. The study of changes in atomic ratios has shown that the atomic $\mathrm{Ca} / \mathrm{P}$ ratio remains constant without significant changes to experimental despite of the increase of the time of stays in the conditions of the experience.

On the other hand, the variation quantity of $\mathrm{HPO}_{4}{ }^{2-}$ ion has shown a gradual decrease according to the increase of the time of treatment in a wet atmosphere of the initial mixtures.

This variation of the ion levels $\mathrm{HPO}_{4}{ }^{2-}$ is certainly due to the balance that will be established between the reactants. Indeed, by infrared absorption spectroscopy, there was an increase of the intensity of the bands associated with the $\mathrm{OH}^{-}$ions. Thus, it is possible to accept, as has been repeatedly shown by J.C. HEUGHEBARET and G. MONTEL [20] that the observed $\mathrm{OH}^{-}$ions are indeed derived from the hydrolysis intercrystalline phosphate ions during the formation of the apatite by:

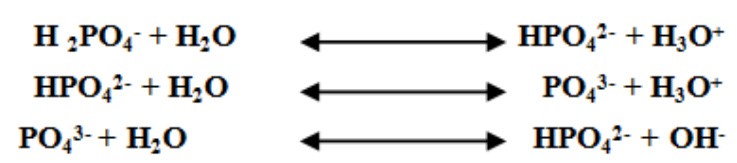

Similarly, chemical analysis reveals a significant loss $\mathrm{CO}_{3}{ }^{2-}$ ions and $\mathrm{NH}_{4}{ }^{+}$of the initial mixture. This ion loss is accompanied by the disappearance of $\mathrm{H}_{2} \mathrm{PO}_{4}{ }^{-}$ions, most likely by the following reactions:

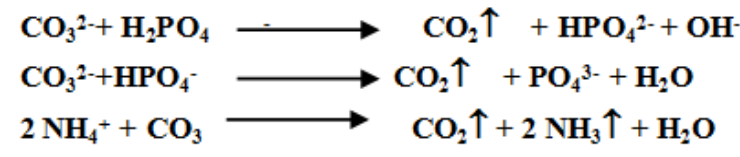

In these circumstances, it appears that the synthesis of the apatite structure of calcium phosphates is due to the hydrolysis of the present products in the initial mixture. This reaction is probably favored by the medium saturated with water vapor and a priori this exchange medium may be the film which has formed on the surface of powders of the salts.

Moreover, the evolution of calcium phosphate occurs in the majority of cases in solution or by a dissolution/reprecipitation mechanism [15-12-10-22] or by a topotactic mechanism [22-24].

Also, in the conditions of our experiences, we can design the important role of the water film adsorbed on the decomposition of initial mixtures of salts in moist atmosphere apatite. Therefore, the reaction mechanism may be possible in two successive steps:

Dissolution of a portion of the ions of the initial mixture to the surface by the adsorbed water film. Once the saturation condition is satisfied, there may be nucleating (or germination). This step, required in the crystallization process, is the formation of nuclei of sufficient size to enable subsequent growth. The nucleation process can occur either homogeneously or heterogeneously in the presence of foreign particles that act as nucleation sites [25-27]. In our case, it is the model of homogeneous nucleation which was chosen view the recovered samples are single phase and no foreign stage was detected.

\section{Conclusion}

Beyond 48 hours of stay time in the conditions of the experiment, the atomic ratio $\mathrm{Ca} / \mathrm{P}$ of the treated samples remains practically stable. The analysis of the diagams of $\mathrm{X}$-ray and the infrared absorption spectroscopy of the different phosphate salts, after treatment, have shown the formation of a calcium phosphate which has a poorly crystallized apatite structure. Also, when this time increases, the state the crystallization of the apatite was improving. Furthermore, for the characterization of the two products which were treated for 21 days then calcined at $900^{\circ} \mathrm{C}$, the XRD and the IR have showed an evolution of the initial salts to a biphasic apatite composed of the phosphocalcium hydroxyapatite and the $\beta$-tricalcium phosphate. 


\section{References}

[1] S.L. Law, W.Y. Lo, F.M. Lin, C.H. Chang, Int. J. Pharm. 84 (1992) 16.

[2] K. Yamamura, H. Iwata, T. Osada, T. Yotsuyanagi, T. Nabeshima, Jpn. J. Pharmacol. 66 (1994) 433.

[3] C.T. Laurencin, M.A. Attawia, L.Q. Lu, M.D. Borden, H.H. Lu, W.J. Gorum, J.R. Lieberman, Biomaterials 22 (2001) 1271.

[4] R. Suen, S. Lin, W. Hsu, J. Chromatogr. A 1048 (2004) 31.

[5] P.W. Brown, B. Constantz, Hydroxyapatite and Related Materials, CRC Press, Boca Raton, FL, 1994, p. 45.

[6] W. Suchanek, M. Yoshimura, J. Mater. Res. 13 (1998) 94.

[7] S.Raynaud, E.Champion, D.Bernache-Assollant, P.Thomas Biomaterials 23 (2002) 1065-1072

[8] S. Kannan, J.H.G. Rocha, J.M.G. Ventura, A.F. Lemos, J.M.F. Ferreira Scripta Materialia 53 (2005) 1259-1262

[9] Hongquan Zhang, Ming Zhang Materials Chemistry and Physics 126 (2011) 642-648

[10] R. Elosrouti et B. Sallek Phosphorus, Sulfur, and Silicon and the Related Elements vol 198, issue 1 p 124-133 (2013).

[11] Xing Zhang, Kenneth S. Vecchio Journal of Crystal Growth 308 (2007) 133-140

[12] R. Elosrouti et B. Sallek. Anal chemestry T.S.I, vol 11, issue $4 \mathrm{p}$ $137-142(2012)$.

[13] A. Rodrigues, Thèse de doctorat, 1998 I.N.P Toulouse.

[14] A. F. Lemos, J. H. G. Rocha, S. S. F. Quaresma, S. Kannana, F.N. Oktar, S. Agathopoulos, J. M. F. J Ferreira, Eur. Ceram. Soc. 2006, 26, 3639-3646.

[15] A.Rodrigues, A. J. Lebugle, Solid State Chem. 1999, 148, 308-315.

[16] (JCPDS \#09-0432).

[17] (JCPDS \# 5-586).

[18] (JCPDS \#09-0169).

[19] JC. Heughebaret. Thèse, 1977, I.N.P.T, Toulouse, France.

[20] J.C. HEUGHEBARET, G. MONTEL Coll. Int C.N. R. S. 1973, Physico-chimie et cristallographie des apatites d'intérêt biologique, 283-293.

[21] H. F. MILHOFER, H. BILINSKI, 1973, Coll. Int. C. N. R. S Physico-chimie et cristalliographie des apatites d'intérêt biologique, 303-310.

[22] W.E. BROWN, W.SCHROEDER LEROY, J.S. FERARIS, 1979 J. Phys, Chem, 83(11), 1385-8.

[23] W.E. BROWN, M. MATHEW, M.S. TUNG,1981 Prog. Crystal Growth Charact, 4, 5987.

[24] B.B. TOMAZIC, M.S. TUNG, T.M. GREGORY, W.E. Brown, 1989 Scan. Microsc, 3, 1, 119-127.

[25] J.W. MULLIN, 1972 CRC press, Cleveland, Ohio.

[26] M.OHARA, R.C REID, 1973 prentice Hall Inc.

[27] M. FRECHE, thèse, 1989 INPT, Toulouse, France. 